\title{
ENTREPRENEURSHIP AND MANAGEMENT OF SMALL ENTERPRISES: AN OVERVIEW OF AGRICULTURAL ACTIVITIES IN THE MOPANI DISTRICT MUNICIPALITY
}

\author{
Aaron Ramodumo ${ }^{1}$ ORCID: 0000-0003-2275-8413, \\ Joel Chigada ${ }^{2}$ ORCID: 0000-0002-7633-8345
}

\begin{abstract}
:
Background: This study analysed entrepreneurial dynamics, activities and challenges confronting small agricultural businesses in the Mopani District Municipality in Limpopo, South Africa. Mopani is a rural district municipality and home to 1,2 million people of whom $77 \%$ live below the poverty line. Agriculture is a major income-generating sector for many disadvantaged communities in rural areas of South Africa, and it plays a significant role in the economy.

Objectives: The objectives of the study were to investigate the operational practices that contribute to the success/failure of emerging agricultural small enterprise owners in their agricultural activities within Mopani District - a district with large numbers of highly competitive and commercial farmers. In addition, the study suggested interventions that could help smallholder farmers to sustain their income-generating businesses.

Method: A qualitative research method was adopted to gain insights from 30 small agricultural businesses, which included crop, poultry and diversified or mixed production. Different data collection techniques (interviews, document analysis and observations) were used to collect data and increase the trustworthiness of the research findings.

Results: The majority (68\%) of farm owners had no finance to start their own personal businesses, except that they received funding (financial start-ups) from the Municipality, the Comprehensive Agricultural Support Programme (CASP) and other agencies. Thirty-two per cent (32\%) started their businesses on their own without municipal assistance, but they received funding later on. The study revealed that entrepreneurial practices and procedures of running small agricultural enterprises were multidimensional and diverse. Entrepreneurs lacked business management skills, vision, capital and access to markets.

Conclusions: While the number of jobs in the large enterprises is decreasing, and government battles in creating conditions for job opportunities, the number of people seeking employment is growing every year. This causes an increase in unemployment in the country. The successful enterprises established income-generating activities that met the needs of their communities. Successful farmers seem to have an endless array of internal and external constraints such as internal efficacy, farm knowledge, business practices, poor marketing, natural disasters and harsh climate conditions amongst emerging farmers. Government should focus their attention on entrepreneurship training, as this is the avenue for incubators and the engine room for economic growth. This would create the much-needed business sustainability, employment opportunities and alleviate poverty in communities.
\end{abstract}




\section{INTRODUCTION, BACKGROUND AND PURPOSE}

The public reforms that began immediately after 1990 in South Africa, laid a foundation for an increased number of small businesses, with government identifying growth and economic empowerment as key to the sustainable growth of the economy (Nel, 2001). With 7.2 million (32.5\%) of South Africans unemployed, it became essential that every opportunity for job creation and the generation of sustainable jobs, was nurtured. More income-generating programmes and projects begun as a way of addressing widespread poverty and unemployment. Small enterprises were perceived to have an important role to play in economic growth (Ayandibu \& Houghton, 2017). With the support from various organisations and state organs, some previously disadvantaged individuals began to test business opportunities and profit. For the first time in decades a whole range of self-employed small businesses (small agricultural enterprise activities in Mopani) started and gained speed as a consequence of the reforms that took place with the dawn of democracy. Government's idea was to encourage people to do this for themselves to reduce poverty and to create jobs for South Africans. Small agricultural enterprises established income-generating activities that met the needs of their communities. This further contributed to a growth in the number of selfemployed individuals and an increasing recognition of the importance of small enterprises in South Africa (Akintude, 2020).

In 1994, the new African National Congress (ANC) led government made firm commitments for a programme of development and building the economy in order to meet basic needs, increase output in all sectors of the economy, and to open up previously suppressed economic and human potential in rural areas (White Paper on Reconstruction \& Development Programme, 1994). Despite the commitment to the goal by every sphere of government, successful small enterprises in Mopani are still few and far behind regarding development. Since 1994, the area did not have as many emerging farmers as they envisaged. Few people started farming and learnt some farming business management skills, but within a short time they never got going (Fakoti, 2014). Although the district has great agriculture potential, it has a 60,4\% unemployment rate, it remains characterised by low levels of economic activity and extreme conditions of poverty. Almost $80 \%$ of people in Mopani live in rural villages and the majority struggle to survive. About $39 \%$ of the working population work on the farms (Mopani District Municipality Integrated Development Plan, 2018).

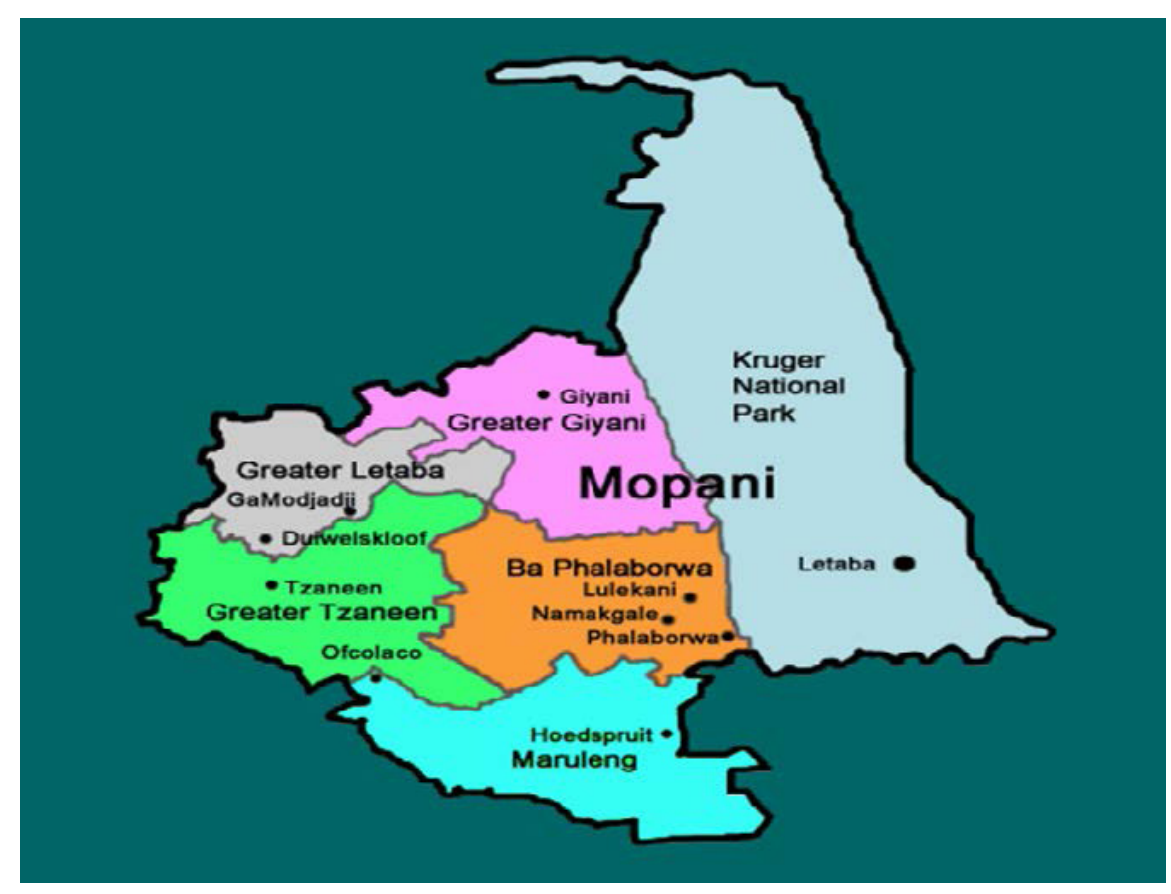

Figure 1: Map of Mopani District, Limpopo Province

Source: http://demo.demarcation.org.za.info

With reference to the importance of small enterprises that are a major subject of considerable interest in government, academia and business in most developing countries, small enterprise development is the road to a progressive realisation of economic freedom and rural development (Chowdhury, 2013). Small enterprise development is identified as something desirable, worth pursuing and that contributes to a vibrant local economy and social development (Dempsey, 2013). Thus, owning and running a small enterprise is a dream for many people. 
Despite the increased attention paid to accelerated small business development, the rate at which small agricultural businesses fail, remains high and little is known about patterns of successes in small businesses. This study on Entrepreneurship and Management in small enterprises in Mopani District Municipality, attempts to understand and identify practices and patterns of how successful agricultural entrepreneurs run their businesses. Agricultural activities are the mainstay for many people in Mopani District Municipality. The challenges confronting small agricultural businesses ventures have been a subject of debate for some time, but there seems to be a dearth of information that suggests long-term solutions. The Global Entrepreneurship Monitor [GEM] (2019) asserts that entrepreneurship plays a significant role in poverty reduction, alleviation of unemployment, and improving the general standard of living. South Africa, like most developing countries in Africa, is grappling with high levels of unemployment, crime and poverty, compounded with a very high rate of inequality (Gini Coefficient of 0.65 points). There are various factors contributing to a high Gini Coefficient, such as the present government's governance style and the legacy of apartheid. The economy has to turn to entrepreneurship to improve economic growth and the standard of living of its people.

By analysing the entrepreneurial activities and challenges faced by small agricultural businesses in Mopani District Municipality, the study reveals continuous training and financial management as some of the issues relating to enterprise development. This also includes the experiences (learning from others) of people involved in these entrepreneurial ventures.

\section{RESEARCH OBJECTIVES AND QUESTIONS}

With reference to the theoretical basis of this study, the following research objectives and questions were formulated:

\subsection{Research objectives}

I. Establishing factors contributing to the success/failure of small agricultural enterprises in Mopani District Municipality.

II. Assessing challenges faced by small agricultural enterprises in Mopani District.

\subsection{Research questions}

I. What factors contribute to the success/failure of small agricultural enterprises in Mopani District Municipality?

II. What challenges do the small agricultural enterprises in Mopani District face?

\section{LITERATURE REVIEW AND THEORETICAL BASIS OF THE STUDY}

\subsection{Overview of Agricultural Entrepreneurship}

The concept 'entrepreneurship' conjures much debate and a variety of interpretations. It is derived from the French word 'entreprende', meaning to undertake (Kuratko \& Hodgets: 2001) or a person who undertakes (Massey, 2005). It refers to capacity and willingness to undertake and manage a productive venture with all attendant risks, while seeking profit as a reward. Acs and Audretsch (2005) assert that the concept of entrepreneurship relates to operations and a pursuit of new opportunities or starting a new venture from limited resources in order to maximize profit. While Douglas (2004) states that entrepreneurs adopt various or alternative strategies best suitable to achieve their goals. It therefore stands to reason that an entrepreneur is a rational person who mobilises all resources necessary to produce and market a product that answers a market deficiency - a contributor to the process of creativity and innovation. In addition, entrepreneurship is a perceived profit opportunity and initiated action to fill currently unsatisfied needs, or it is to improve inefficiencies, to perceive an opportunity, and to create an organisation to pursue it. According to Mtaputi, Nkosi and Sebetlene (2007), entrepreneurs would assume the risk for a business, and they would expect that to make a profit is their prime factor in an entrepreneurial function.

Small agricultural businesses are underpinned by a general theory of entrepreneurship with three critical assumptions. The first assumption is that opportunities are objective. Opportunities have an objective component, and these opportunities exist whether or not an individual recognises them (Shane, 2003). These opportunities are derived from the attributes of the market wherein an entrepreneur contemplates to take action. Thus, if an entrepreneur understands the attributes or structure of a market, they will be able to exploit economies of scale in order to seize the opportunities. Therefore, understanding entrepreneurial opportunities is important, because the characteristic of an opportunity influences the very value that opportunity might create.

The second nexus is that entrepreneurship requires differences in people and that these differences manifest themselves in their cognitive ability to recognise opportunities. Thus, individuals are entrepreneurial and alert to 
existing opportunities (Kirzner,1973). Entrepreneurial alertness is not a deliberate search, but a constant scanning of an environment by an entrepreneur who notices market imperfections. These opportunities are not assumed to be objective phenomena formed by exogenous shocks to a market only, but they are rather endogenously created by the actions, reactions and enactment of entrepreneurs who explore ways to produce new products or services (Venkataraman, 2003).

The third assumption is that entrepreneurs are risk bearing. Risk bearing is a necessary part of the individual entrepreneurial process (Shane, 2003). Starting a business venture is in itself a risk, because the outcome is not known but hoped for. The decision-making context within which entrepreneurs choose to exploit an opportunity is assumed to be risky, rather than uncertain. A decision-making context is risky, if at the time as a decision is being made, decision makers can collect enough information about a decision to anticipate possible outcomes associated with that decision, and the probability of each of those possible outcomes is fulfilled. Agricultural opportunities are created through a series of decisions to exploit a potential opportunity. This includes analysis of the market and through learning. Therefore, opportunities do not have an existence independent of the actions of an entrepreneur to discover and create them (Davidsson, 2015).

\subsection{Factors contributing to the success/failure of small agricultural entrepreneurs}

Effective and efficient business management is essential if small businesses are to survive, succeed and thrive. There are many variables postulated as critical factors that contribute to success or failure of businesses. These include, amongst others, the notion that an entrepreneur who wants to succeed would have to study the success of others, identify business role models, network with other business professionals, and he should have commitment, determination, leadership, creativity, self-confidence and adaptability, motivation to excel and develop (Kroon, 1998), both intrinsic and acquired. Commitment and determination are seen as more important factors as these enable entrepreneurs to overcome incredible obstacles and also compensate extremely for other weaknesses. Du Plessis, Jooste and Strydom (2005) state a number of factors contributing to the success of entrepreneurs: experience, education, ability of business to make profit, business growth, marketing and sales, customer management, bookkeeping/accounting practices and turnover (volume of sales during the financial year). These factors provide critical information for improving business, reduce the risk of failure and increase success. They are often considered as yardstick measures that suggest that there is a relationship pattern between acquiring such variables and they are positively associated with business success. This further suggests that lessons learnt from others (role models) assist in the development of effective strategies for business success.

While the study emphasised the importance of small agricultural businesses as the engine for economic growth, there other small businesses that are rapidly plummeting, owing to knowledge and skills deficiencies (management and entrepreneurial competencies) that contribute to inappropriate and uncompetitive management of businesses. These factors include inexperience in business management, poor financial management, lack of accounting records and lack of planning. Failure to manage finances and inability to apply financial management practices, suggest nothing else but business mortality. To elucidate further, the best way to overcome failure, would be the acquisition of the necessary aptitudes, knowledge and skill through training and counselling. The consequence of small business failure is a serious matter for directly involved business owners and stakeholders, and it requires deeper understanding to reduce small business discontinuity.

\subsection{Challenges facing small agricultural entrepreneurs}

Nik (2006) identifies numerous constraints that small businesses experience, which often lead to a failure to grow. A common constraint has been the general management of small enterprises, competition, and how they have been conceived. This includes limited access to training, lack of skills which reduces enterprise productivity, technological innovation and competitiveness. SMEs are failing to embrace agricultural technologies (loT) - just a mere desktop computer to capture their records and assess their financial costs. This is also attributed to low computer literacy ratios, limited education and a lack of understanding of how technologies can facilitate information sharing. Another challenge is a lack of financial resources. With reference to the rate of collapse of SMEs, financial institutions have a leg to stand on in refusing to finance such ventures (GEM, 2016). Despite numerous institutions providing training and advisory services, most entrepreneurs still have a gap in the application of what they have learnt. Of the many reasons for small business failure, poor management methods, experience and lack of relevant business expertise in areas, such as financial management (e.g., mismanaging money, poor accounting and inability to develop and monitor financial statements), have emerged (SMME Forum, 2004).

Given the business models used by most SMMEs, most financial institutions believe that these models are not 
sustainable and therefore they are not willing to advance lines of credit or loans. In addition, if the entrepreneurial venture does not have a traceable financial and trading history, there are no chances of funding from financial institutions (GEM, 2016). Commercial banks and financial institutions are not ready to support businesses without a trading history. Financial challenges continue to confront SMMEs in most parts of the African continent.

According to the Organisation for Economic Co-operation and Development [OECD] (2001), failure to harness and embrace agricultural technologies can be consequential to SMMEs. This does not mean using state of the art technologies like drones, but just a basic computer to capture, store and retrieve information about agricultural trends might help start-ups. However, limited computer literacy levels, limited education, inability to access internet services and failure to appreciate how technologies can facilitate information sharing, are key impediments to adoption of agricultural technologies (OECD, 2001). With reference to the rural set-up of the study, there are a myriad of other challenges such as transportation of produce, inability to access markets and poor marketing strategies (GEM, 2016).

\subsection{Interventions to improve the survival of small agricultural entrepreneurs}

There are various interventions to improve small agricultural entrepreneurs. This includes government funding, access to markets, and a collaborative/cooperative approach to the established small business development centres that must focus on the necessary skills and needs of local entrepreneurs, provision of appropriate, relevant, problem-based entrepreneurship training programmes, business advisor services and market information (Kahan, 2012). People venturing into small enterprises need to have certain skills, personal attributes and understanding (augmented by vocational training) of business environment.

Moloi (2014) states that some SMMEs, especially in the retail sector, have developed supply chain networks. This is an apparent reference to spaza shop owners (foreign nationals) that pool their financial resources together to approach wholesalers for discounted bulk purchases. Effectively this reduces the cost price and improves the spaza shop owner's profit margins. Therefore, cooperative strategies can give agricultural farmers bargaining power in the market and ameliorate some of the business management skills facing small agricultural business ventures.

Zambonini (2012) suggests government funding and support would help alleviate some of the problems. If government, through the Small Enterprises Development Agency (SEDA) and other agencies provide training and development programmes, the SMME sector would be vibrant and become the nexus for incubation and innovation. Thereby they would become centres for economic growth and development. With such initiatives aimed at creating sustainable businesses, support might also come in the form of access to markets and infrastructure development (Moloi, 2014).

\section{RESEARCH METHODOLOGY}

Chalmers (2002) defines ontology as the study of being where reality is constructed within the human mind. Proponents of objectivism state that the researcher's beliefs and opinions should not influence the nature of reality, therefore, the researcher should be detached from the subjects under investigation. The nature of the study required the researchers to interact and immerse themselves with participants, thus, a subjectivism ontological perspective led to the adoption of an interpretivist philosophical stance. Proponents of subjectivism believe that the view of reality depends on the mind and it is socially constructed (Neil, 2019). Given the nature of the study, the researcher believed that reality was multi-layered and complex. Thus, there were multiple interpretations of the concept of entrepreneurship, especially in the agricultural sector. Saunders, Lewis and Thornhill (2016) state that when studying a phenomenon, interpretivism applies research techniques to help understand how people interpret and interact with their social environment. Subjective human experiences and perceptions shape the ontological perspective of the study. Bryman and Bell (2015) assert that interpretivism uses meaning-oriented methodologies with in-depth interviews - observation that relies on subjective relationships between the subjects and the researcher. An exploratory research design was used in this study, because the objective was to use multiple qualitative data collection techniques (Leedy \& Omrod, 2015).

Qualitative data was gathered through in-depth interviews, participant observation and document analysis. These data collection techniques complemented the exploratory research design to obtain evidence which addressed the research questions and objectives. Saunders et al. (2016) state that in qualitative research, the researcher interacts with subjects to gain preliminary insights into decision problems and activities of small agricultural entrepreneurs. Data was collected from thirty (30) participants through interviews, documents analysis and by observing the practices of five of the most successful small agricultural business owners in Mopani District Municipality. Rich and 
timely data was collected, because the researchers could record accurate participants' behaviour and preliminary insights (Creswell, 2014).

Data collected was organised and classified into categories or themes. Categories that were inductively derived from data were coded to identify emerging critical themes emerging from raw data, broad patterns, linkages and relationships that characterize the case more broadly than a single piece of information. The purpose of coding was not only to describe, but more importantly to acquire understanding of a phenomenon of interest, to obtain a general sense of the information to identify patterns and reflect on its overall meaning, or to make sense of the data. The researchers collected and analyzed data from several cases. A comparison was made among different entrepreneurs to identify points of major divergence and similarities.

\section{FINDINGS}

Qualitative data was gathered through in-depth interviews with 30 participants. Consent was granted by each participant to record their opinions during the interviews. All transcriptions were exported to NVivo 12 for coding and identification of themes/patterns. Clarke and Braun (2014) state that thematic data analysis is not merely a process of summarizing data, but the researcher has to identify and interpret themes/patterns of meaning across qualitative data. Researchers were involved in the interviews, they made notes, and then they generated codes for all the themes. Literature has deep-seated assumptions and propagations for modern business practices without acknowledging the nature and context of farming practices in rural areas, farmers' alternative decision processes resulting from various circumstances, and how this, in turn, improved their business practices. Participants stated the following:

Most of us here do not have business and financial management skills.

As you can see, the way we operate shows that we do not have any vocational training in agriculture.

Traditional agricultural tools such as hoes and ox-drawn ploughs, scotch carts are widely used amongst all rural farmers. We do not have the latest technologies to help us with our farming activities.

Although certain elements (such as vocational training and financial management) are prerequisites for the success of small agricultural businesses, it is an entrenched bias. However, the above extracts suggest that participants did not have formal vocational training. The views raised by participants showed that rural communities relied on traditional agricultural tools and methodologies. Participants indicated that the lack of business and financial management skills is a big problem impeding their success. The study debunks such a contemporary wisdom, since successful entrepreneurs created opportunities from their mundane realities and value systems (due to the complex and unpredictable nature of business environment). Their practices presented the emergence of a new or organised social entrepreneurship paradigm that transcends the current and orthodox (and perhaps dogma) approaches to business practice. Much as this was the case, financial management and constant workshops on the use of technology in farming and sharing best practices remain important regarding their suitability for the agricultural small enterprises, particularly in the rural Limpopo Province. Some comments from participants were:

We operate our businesses in remote areas; thus, we do not have access to the Internet and other resources to keep us informed.

I do not have business management qualifications, however, from my experience in this agricultural project, I can say that I have relevant experience. If there are opportunities to get training and development, I would be grateful.

Lack of financial resources affects all of us here in Mopani District.

It is acknowledged that most rural communities in South Africa are poor, do not have adequate infrastructure and are severely affected by poverty. Therefore, the view raised by the participants are acknowledged. Remote areas in South Africa do not have access to the Internet or other resources that are relevant to information sharing. The study found elements that may be relevant to understanding successful farming practices (e.g. thinking on your feet when confronted by certain situations) and to also broaden the epistemological horizons, which are largely ignored in policy circles and scholarly literature, regardless of the growing evidence of its value in the development of small enterprises. 
We do not have a readily available market for our produce. This exposes our perishable products.

Some markets force us to leave our produce and then we get paid after a long time. By then, we would have incurred additional expenses such that by the time we get paid, the value of the money would have been eroded.

After production, some farmers would distribute their produce and expect payment later. This ensures avoiding the challenges of poor sales and of not completely losing their produce. At the same time, it builds social relationships with customers. Whereas those that succeeded presented the attributes associated with a plethora of literature that emphasized the importance of learning from others and having financial management, those that failed reflected their inability to take risks under the circumstances and they also failed to manage their finances. The most important finding was that small enterprise managers do have wishes and desires which reflect their unique interests, because various factors induce or persuade small-scale farmers to do business according to how they deemed fit. This was reflective of successful farmers' ability to do what is best for them and to have the courage to follow their passion. This risk-taking attitude, according to Kroon (1998), was some form of determination, an attribute which some did not have. Farmers have shown that no matter what they may have learnt, they would act in their own interests and choose what they believe will help them to reach their goals. This is a reflection that repackaged textbook material is inadequate to understand entrepreneurs' situations. In order to promote sustainable entrepreneurship and existing interventions, couples with entrepreneurial intuition and tolerance to risk, suggest a radical shift in approaches that underpin interventions for successful small agricultural enterprises.

Out of thirty (30) small enterprise farm owners interviewed, $40 \%$ remained in operation (the majority of which started on their own) beyond five years, and $60 \%$ collapsed within the first three years of their start-up. This shows that funding alone is inadequate for successful small business, and that a combination of various attributes such as determination and courage is more appropriate. The majority of those that failed were not self-starters but had been retrenched in their previous employments and they opted to start businesses due to funds made available to them. Clearly, funding alone cannot make one successful. Respondents were asked to share their experiences of the challenges they encountered, and also how they managed such challenges for the business to survive. A summary of the challenges facing agricultural farmers in Mopani District is illustrated in Figure 1 below.

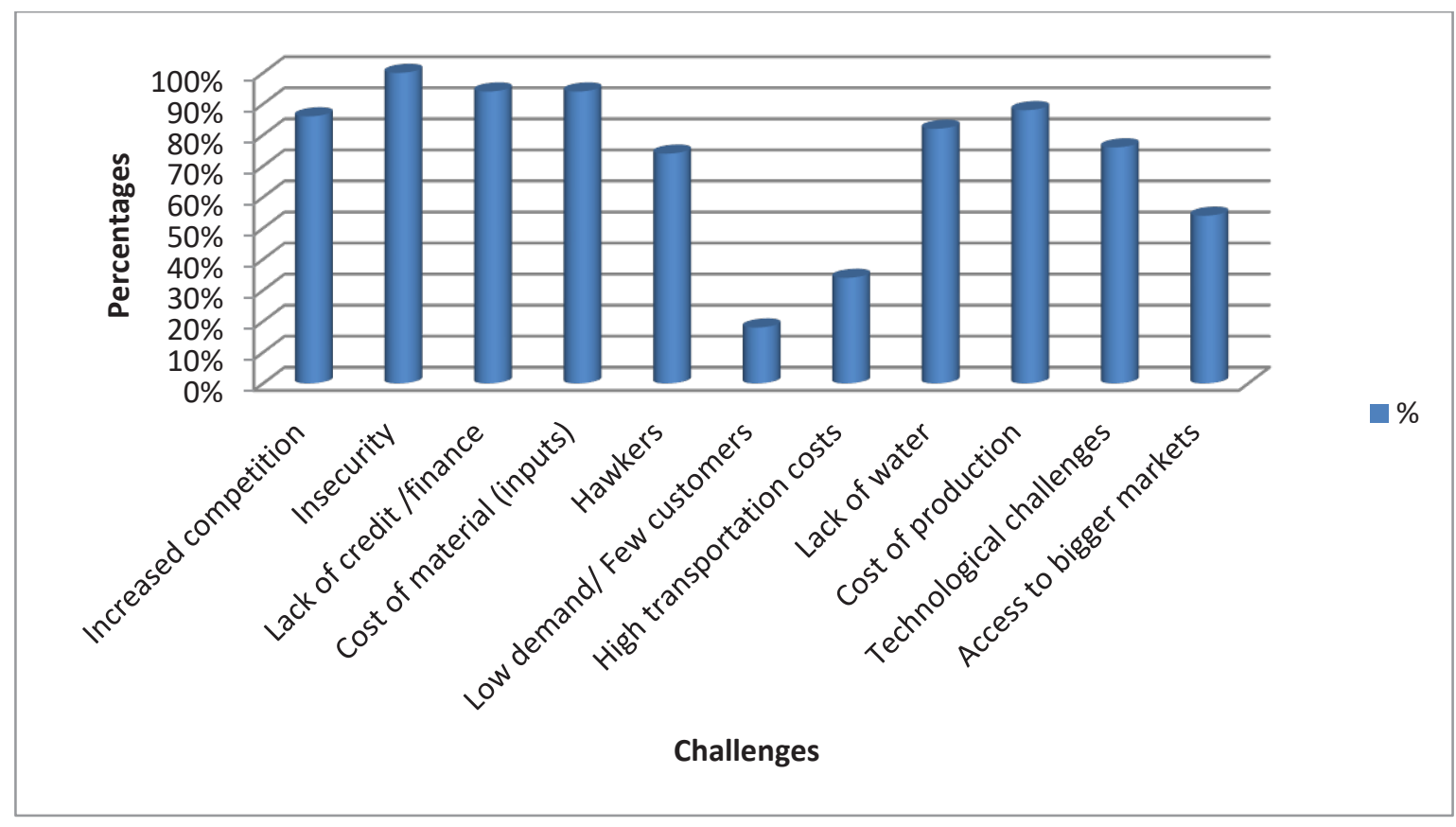

Figure 1: Challenges facing small enterprises

Chicken farmers further had the challenge of chickens pecking one another and cannibalism (chickens eating one another when there is not enough food), the seasonal outbreak of the Newcastle disease, Coccidiosis disease which was simply transmitted from one bird to the other through their droppings, and the Gamboro disease - an 
infectious bronchitis which is the infection of the breathing system which chickens are susceptible to. Crop farmers complained about the use of agents who sold vegetables at the market on behalf of farm owners. Their tolerance to risks was good enough to keep them going. Accordingly, agents rent floor space for farmers' produce from the owner of the market. When such produce is sold, an agent would get $7.5 \%$ of the gross sale of products, while the owner of the market would take his amount for the rented space. Thus, the market then pays the remaining balance to the farmer who has to pay employees, transport costs, make some savings, spend money on other input costs, and perhaps rent a tractor. Although they were aware of these circumstances, their ability to network with other wholesalers enabled them to salvage the little they could. Their main challenge was summed up as follows:

Ours is struggle and we are not prepared to give up. You cannot water your farm for the entire day using borehole water pump. Otherwise, the machine will be heated and ultimately stop. You either use the other borehole if you have, or else you continue the following day. If I were to pump into the little reservoir, it would take me the entire day and night before reservoir is full. I now have to water the crops in the evening when heat is less, but risk the machine been taken away by thugs. I am somehow forced [to] plant few crops and can't even make money due to competition. What gets worse is when your produce can't sell at the market and yet you have to pay a person who sells produce on your behalf.

Business owners used a number of contacts and their employees to market their businesses locally. Many of them relied on direct local market supply to major supermarkets (though inconsistent) and used word-of-mouth to promote their businesses. Because the establishment of these enterprises was mostly a government initiative, their businesses were featured in the government newsletters (particularly that of various local municipalities) and the local radio stations. This, however, did not happen regularly. Except for these instances, there was limited marketing through word-of-mouth. Local community members and school feeding programmes became their target market for selling their produce. As there was a social relationship between grower and consumer, farmers were geared to sell their crops directly to the consumer.

Financial information serves as a basis for business performance, profitability or failure. Studies showed that the small business success and failure were mostly caused by elements such as cash flow management and recordkeeping. The majority of small agricultural businesses exhibited inadequate financial and accounting management knowledge to enable them to assess whether they make a profit or not. Some attributed their success to commitment and determination (persistence), willing to make personal sacrifices, a drive towards establishing a successful business and getting assistance from others. Advice from other farmers and commitment to the challenges of business has helped many entrepreneurs to make wiser decisions. For many small business owners, dedication and perseverance have served as key to their success and to weather the storm.

\section{DISCUSSION}

Small agricultural enterprises are seen as critical drivers of job creation and generally, economic growth. Besides the major benefits amongst farmers in Mopani, there are various challenges and constraints that they face. Small agricultural business owners faced different challenges, depending on the nature and type of the business they operated. The challenges, such as competition and cost of production, were common. Other challenges experienced by those that failed were, amongst others, overly saturated market, falling prices due to oversupply of similar products, stiff competition, product price reduction to mitigate the risks, access to markets, use of boreholes, input costs, crop diseases such as Nematode and poor road infrastructure from farms to markets that spoiled produce. Lack of collateral which could allow them to secure a loan to expand their businesses, proved to be a major hurdle. Their ability to find other alternatives to keep their business afloat was a sign of sheer determination, which is an attribute associated with most successful farmers.

Successful businesses showed the ability to develop survival mechanisms to withstand and overcome any potential threat to the demise of a business venture through their unconventional business practices. This, according to Du Plessis, Jooste and Strydom (2005), is only possible with people who are determined and prepared to take certain risks. Some showed discipline in finance management through procurement of ordinary farm implements rather than fancy bling cars. Their underlying knowledge of the suitability of a product to certain climatic conditions helped them to succeed (Mtaputi, Nkosi \& Sebetlene, 2007). Although conditions are generally suitable for tomato production in Mopani, they are particularly suitable for conditions in the Greater Letaba. Thus, some form of education is important for successful small agricultural enterprises (Du Plessis, Jooste \& Strydom (2005). Similarly, chicks of chicken farmers in the greater Giyani and Ba-Phalaborwa municipalities died in large numbers due to a heat wave in the area compared to those chicks in the Tzaneen and Maruleng area. This could have been avoided had they been equipped with some basic training of chicken rearing. 
Although most farmers had no relevant education, they became protégés and relied on the advice and practices of other established farmers who often shared information and best practices. Other successful farmers who had some level of experience from their previous businesses, used their previous job experiences to their advantage as prior knowledge appears to have been helpful in their business success. Some may not have acquired preferred knowledge from fine print materials such as the theory learned through textbooks, or the book-based system of learning (education), but through experience based on other aspects which then translates into education. It can be inferred therefore, that prior business experience was helpful in small businesses success. The assumption that if a farmer has a higher level of education it increases their efficiency and success (Shane, 2003) appeared to be disputable. Qualification based on levels of education alone is not necessarily a critical factor for business success. Knowledge of business and its dynamics was found to be more important.

Efforts from small agricultural businesses confirmed the assertion by Wijbenga \& Van Witteloostuijn (2007) that entrepreneurs' internal locus of control (belief that success or failure is a result of the effort and hard work they invest in the farming business), ability to use their door-to-door and nodal point strategy of selling their produce to consumers, and the fact that some of them were well known within communities, had ensured their success. Others survived in business through their traditional marketing and sales at social grants payout points, due to limited access to national market infrastructure which was often monopolized by big businesses (Louw, Jordan, Ndanga \& Kirsten, 2008). Their convenience and social skills, particularly to local customers who buy in bulk for 'stokvel' and for funeral purposes, suggest that such farmers may have entrenched themselves in township economy or in the local town and communities. Farmers' ability to take risks and have relations with customers, went so far as to sell their produce on credit and collect their money weeks later. They give regular customers a few products for free as a gesture of appreciating their support, creating social capital/bonds, to win clients and to foster relations. The mushrooming Shisa-Nyama (chicken grills) on almost every street corner in local towns and bus terminals, strongly reaffirms the efficacy of social entrepreneurship and the power of social media marketing, viral marketing, buzz, or guerilla marketing (word-of-mouth).

The use of diversified farming (chicken, vegetables, piggery) helped to create small agricultural businesses amongst others. Farming diversity mitigated risks, improved cash flow, complemented business against market fluctuation and kept the farm running optimally. Thus, farm diversification seemed to be related to risk management strategies that are devised to withstand price fluctuation, manage income risks, cope with risky agricultural returns, and provide entrepreneurs with some adjustment to changes in the cost of a product.

Whereas agriculture remains a critical component of programs that seek to reduce poverty, attain food security, job creation and economic growth in Mopani, there were various constraints that limited such a contribution. Some of the challenges that led to business failure were a lack of feasibility studies before they could start their businesses (Stott et al., 2014). The fact that some farmers had not conducted any form of feasibility study or market research to ascertain a need for a specific business before venturing into it, remains prevalent, worrying and may have been a possible reason for business failure. Thus, the narrow and unrepresentative slice of available evidence on business opportunities without adequate feasibility, market analysis and management practices, were therefore unfortunately a contributor to business failure (Stott et al., 2014). Going into poultry farming without practical knowledge and peculiarity of the venture, had been a direct invitation to failure. Most business owners generally lacked business training, innovation, creativity and experience, but they still continued to establish businesses. Furthermore, lack of vision, priorities and transition plans further suggest that for some entrepreneurs, starting a business was not opportunity-driven or because of demand considerations (Khapayi \& Celliers, 2016).

A major setback was poor cash flow and record management, which reaffirm viewers of many scholars as reality that exists among many farmers whose businesses had collapsed. According to Ademola, Samuel and Olore (2012), record-keeping is a foundation on which the totality of modern businesses depends. Without record-keeping, it is impossible to ascertain the level of profitability and the level of business susceptibility. Therefore, the usefulness of the information provided by the accounting system through records or bookkeeping, is of cardinal importance in determining business success or failure. Proper records and financial reports (performance measure) are important and provide useful information regarding the financial position of the business.

In business, age is not just a number. As farmers get older, they often become more conservative and reluctant to accept risk. The majority of those that failed, started their businesses at a late stage of their life. According to Bembridge (1984), as farmer activism declines with age, the probability of business failure amongst older farm managers/owners is higher than amongst younger farmers. 
Successful entrepreneurs possess an uncommon degree of dynamism, commitment, creativity and just plain guts than to make immediate profit (Simpeh, 2011). Their efforts were mostly directed to pursue their opportunities and activities to build their businesses, making themselves known and their enterprises real to those people they serviced. Their actions seemed to suggest that building a business was more of a first priority than immediate profit maximization in the short-term. Perhaps this is what distinguished success from potential failure, since what activity entrepreneurs did daily, really mattered, and therefore had a significant influence on the ability of entrepreneurs to create successful ventures (Simpeh, 2011). Most of the owner-managers seem to have acquired their unconventional managerial knowledge and skill through practice, network, learning through experience, social interactions (Chowdhury, 2013), or through learning embedded in their everyday managerial work activities. This involved trial and error learning, making mistakes, and emerging from such mistakes to make the business a success.

\section{RECOMMENDATIONS AND CONCLUSIONS}

Farming can be a highly profitable business and the prospect of having and operating a farm business may be very exciting. Besides a plethora of literature on how to conduct successful business operations, entrepreneurs often do not necessarily operate in accordance with these. No singular management practice was sufficient to explain small enterprise survival, success and growth in Mopani. It is important that sound management practices are championed, in order to ensure a successful small business and avoid business failure. Regular training and using others as role models are recommended for successful small business. Given the emergence of the Corona Virus Disease-2019, small agricultural farmers could consider the adoption of technologies to improve management of their activities. This would include marketing, record-keeping and information management (Chigada, 2014).

\section{LIMITATIONS}

This study confronted methodological and researcher limitations. The first limitation was attributable to the data collection techniques of in-depth interviews and observation. Research participants were not open enough to share their experiences, for fear of the unknown. The authors assured the participants that their information would be used for academic purposes and no personal identities would be revealed to third parties. With reference to observation, some of the participants did not behave in their usual way of conducting business, thus, the study might not have obtained a true behaviour reflection. Some participants might have changed their behaviour to please the authors, or because they were scared, they might not have demonstrated their abilities. These limitations could have been avoided by using different data collection techniques such as a survey. The other limitation faced during the study was the use of the English language. Some of the participants preferred the interviews to be conducted in their vernacular languages for easier communication.

\section{ACKNOWLEDGEMENTS}

The authors acknowledge small agricultural business owners/participants for their time, commitment and information shared during the study. Without your availability and willingness to participate in the study, we would not have completed this research project successfully. The first author (AR) is acknowledged for conceptualizing and developing the study. The second author $(\mathrm{JC})$ is acknowledged for compiling and structuring this research into an academic paper. We acknowledge everyone who contributed to this study in various ways. We thank you for your inputs.

\section{References}

Acs, J.A. \& Audretsch, D.B. (Eds.) (2005). Handbook of Entrepreneurship Research: An interdisciplinary Survey and Introduction. New York: Springs.

Ademola, G., Samuel O. Olore, J. (2012). The Role of Record Keeping In the Survival and Growth of Small Scale Enterprises, Global Journal of Management and Business Research,12(13): 54-66.

Akintude, M.O. (2020). Students' opinions regarding self-employment opporunitiesin agriculture, South African Journal of Agriculture, 48(2):1-8.

Alvarez, S. (2005). Theories of Entrepreneurship. Delft: Now.

Ayandibu, A.O \& Houghton, J. (2017). The Role of Small and Medium Scale Enterprise in Local Economic Development, Journal of Business and Retail Research. Vol.11, No 2, 133-139.

Bembridge, T. (1984). A system apprach to study Agricultural Development Problems in Transkei. Stellenbosch: Unpublished PhD.

Bryman, A. \& Bell, E. (2015). Business Research Methods. $5^{\text {th }}$ Edition. Amazon Business. CA. 
Chigada, J. (2014). The role of knowledge management in enhancing organisational performance in selected banks in South Africa: University of South Africa: Published PhD.

Clarke, V. \& Braun, V., 2014. Thematic Analysis. In: Encyclopaedia of Quality of Life and Well-Being Research. Dordrecht: Springer.

Chowdhury, M. (2013). Success Factors of Entrepreneurs of Small and Medium Sized Enterprises: Evidence from Bangladesh, Business and Economic Research, 3(2), 38-52.

Creswell, J. W. (2014) Research design : qualitative, quantitative, and mixed methods approaches. 4th edn.

Creswell, J. W. (2015). Research Design: Qualitative, Quantitative, and Mixed Methods Approaches (4th ed.). Sage Publishing Inc.

Creswell, J. W., \& Plano Clark, V. L. (2011). Designing and Conducting Mixed Methods Research (2nd ed.). SAGE Publications.

Davidsson, P. (2015). Entrepreneurial opportunities and entrepreneurship nexus: A re-conceptualisation, Journal of Business Venturing,30: 674-695.

Dempsey, I. (2013). State of Entrepreneurship in South Africa: Entrepreneurship Dialogue. Johannesburg: FNB \& Gordon Institute of Business Science.

Douglas, D. (2004). Grounded theory and the 'And' in Entrepreneurship, Journal of Business Research Methods, 2 (2): 59-68.

Du Plessis, P.J., Jooste, C.J \& Strydom, J.W. 2005. Applied Strategic Marketing. Sandton: Heinemann Publishers (Pty) Ltd.

Fakoti, O. (2014). The Causes of the Failure of New Small and Medium Enterprises in South Africa, Mediterranean Journal of Social Sciences, 5 (20): 922-927.

Global Entrepreneurship Monitor Report (2015-2016). Available from: www.gemconsulting.org-report. [Accessed: 20 May 2021].

Global Entrepreneurship Monitor Report (2017-2019). Available from: www.gemconsulting.org-report. [Accessed:19 May 2021].

Kahan, D.(2012). ENTREPRENEURSHIP in farming. Available from http://www.fao.org/uploads/media/5EntrepreneurshiplnternLores.pdf. [Accessed: 05 September 2021]

Khapayi, M. \& Celliers, P.R. (2016). Factors limiting and preventing emerging farmers to progress to commercial agricultural farming in the King William's Town area of the Eastern Cape Province, South Africa, South African Journal of Agricultural Extension, 44(1): 25-41.

Kirzner, I.M. (1973). Competition and Entrepreneurship. Chicago: University of Chicago Press.

Kroon, J. (1998). Entrepreneurship: Start your own business. Pretoria: Kagiso.

Kuratko, D.F. \& Hodgetts, R.M. (2001). Entrepreneurship, a Contemporary Approach. 5th ed. Orlando: Harcourt College.

Leeds-Hurwitz, W. (2009). Social construction of reality. In S. Littlejohn, \& K. Foss (Eds.), Encyclopedia of communication theory. (pp. 892-895). Thousand Oaks, CA: SAGE.

Leedy, P. D., \& Ormrod, J. E. (2015). Practical Research Planning and Design (Eleventh edition ed.). Pearson Education Limited

Loasby, B. (2002). The organisational basis of cognition and the cognitive basis of organisation: The economics of Choice, Change and Organisation, Chaltenham: Edward Elgar.

Louw, A., Jordan,D., Ndanga, L \& Kirsten, F.J. (2008). Alternative Marketing options for small-scale farmers in the wake of changing agri-food supply chains in South Africa. Agrekon, 47(3):287-308.

Massey, C. (2005). Entrepreneurship and Small Business Management in New Zealand. New Zealand: Pearson Prentice Hall.

Moloi, R. (2014). Exploring the Barriers to the Sustainability of Spaza Shops in Atteridgeville, Tshwane. Master's Dissertation in development studies, University of south Africa, Pretoria. 
Mopani District Municipality Integrated Development Plan. (2018). Available from http://www.mopani.gov.za/docs/ idp/final\%20Mopani\%202018\%202019\%20Versions\%203.pdf [Accessed: 14 June 2021].

Mtapuri, O., Nkosi, N. \& Sebetlene, S. (2007). Entrepreneurship. Sandton: Heinemann.

Nel, E. (2001). Local Economic Development: A Review and assessment of its Current Status in South Africa, Urban Studies, 38(7):1003-1024.

Nik, M. H. (2006). Supporting the Development of SMEs: Bridging The Services Gap. Hong Kong: Small and Medium Practices Forum.

Organisation for Economic co-operation and Development, 2001). Adoption of Technologies for Sustainable Farming Systems. Available from https://www.oecd.org/greengrowth/sustainable-agriculture/2739771.pdf [Accessed: 05 September 2021].

Saunders, M., Lewis, P. and Thornhill, A. (2016). Research methods for business students. 10th Edition. Harlow: Prentice Hall.

Shane, S. (2003). A General Theory of Entrepreneurship: The Individual-Opportunity Nexus. Massachusetts: Edward Elgar Publishing, Inc.

Shane, S. (2000). Prior Knowledge and the Discovery of Entrepreneurial Opportunities. Organisation Science, 11(4), 448-469

Simpeh, K.N. (2011). Entrepreneurship theories and empirical research: A summary review of the literature, European Journal of Business and Management, (3): 1-8.

SMME Forum. (2004). Enabling sustainable development. Retrieved 4 May 2006 from http://www.theforum.org.za/ HomePage1.aspx

Statistics South Africa. (2020). Quarterly Labour Force Survey. Available from: https://www.statssa.gov.za/ publications/P0211/P02111stQuarter2020.pdf [Accessed: 12 June 2021].

Stott, D., Lee, E., Nichols, E. \& Folk, F. (2014). Feasibility study of Small/Medium farm product distribution system in the Lower Mainland. Retrieved on 15/06/2021 from https://www.refbc.com/sites/default/files/FFCF-Report-6Small-Medium-Farm-Product-Distribution-System-Development.pdf

Venkataraman, S. (2003). A General Theory of Entrepreneurship: The Individual-opportunity Nexus. Massachusetts: Edward Elgar Publishing.

White Paper on Reconstruction and Development Programme. (1994). Government Gazette No 16085. Cape Town: Parliament of the Republic of South Africa.

Wijbenga, F.H., Van Witteloostuijn, A. (2007). Entrepreneurial locus of control and competitive strategies - The moderating effect of environmental dynamism, Journal of Economic Psychology, 28(5):566-589.

Yin, R.K. (2003). Case Study Research: Design and Methods. Thousand Oaks: Sage.

Zambonini, L.(2012). South Africa failing its entrepreneurs. [Online] Available at: www.thehopefactory.co.za [Accessed 23 May 2021]. 